under intensive care observation may be a safe alternative to mechanical ventilation in patients with severe pneumatosis cystoides and chronic respiratory insufficiency.

Requests for reprints should be sent to Dr N O Klausen.

'Ellis BW. Symptomatic treatment of primary pneumatosis coli with metronidazole. Br Med $71980 ; 280: 763-4$.

2 Down RHL, Castleden WM. Oxygen therapy for pneumatosis coli. $\mathrm{Br}$ Med F 1975;i:493-4.

${ }^{3}$ Andersen JB, Olesen KP, Eikard B, Janser E, Qvist J. Periodic continuous positive airway pressure, CPAP, by mask in the treatment of atelectasis. Eur 7 Respir Dis $1980 ; 61: 20-5$.

${ }^{4}$ Edwards G, Leszczynski SO. A double-blind trial of five respiratory stimulants in patients in acute ventilatory failure. Lancet $1967 ; \mathrm{ii}: 226-9$.

${ }^{5}$ Fraimow W, Diamond P, Cathcart RT. Ventilatory response of patients with pulmonary emphysema to doxapram hydrochloride. $\mathrm{Am} \mathcal{J} \mathrm{Med} \mathrm{Sci}$ $1965 ; 249: 150-62$.

(Accepted 23 March 1982)

Herlev University Hospital, DK 2730 Herlev, Denmark

$\mathrm{N}$ O KLAUSEN, MD, senior registrar in anaesthesia

E AGNER, MD, senior registrar in medicine

L TOUGAARD, MD, senior registrar in medicine

B SØRENSEN, MD, senior registrar in anaesthesia

\section{Simple and effective method of removing starch powder from surgical gloves}

Surgical glove powder shed during operative procedures is potentially hazardous. ${ }^{1-3}$ The infrequent but troublesome effects of iatrogenic starch peritonitis after intraperitoneal surgery has stimulated glove manufacturers to print a warning on each packet of gloves and a recommendation to remove surface powder. Sterilised maize starch is used to prevent gloves sticking together during production and packaging. Several methods of removing starch powder have been described, ${ }^{4}$ in particular an easy method with a quick, reliable test of efficacy ${ }^{5}$; this has now been evaluated.

\section{Method and results}

After surgical gloves have been put on $10 \mathrm{ml}$ of povidone-iodine surgical scrub (Betadine) is applied and the cleansing process continued for one minute. During this time the non-ionic surfactant detergent in the surgical scrub mobilises the starch granules from the surface of the glove. The iodine in the scrub combines with the starch to form blue-black starch iodide. The mixture is then washed off the gloves by rinsing under running sterile water $(500 \mathrm{ml})$ over 30 seconds. Separation of the opposed forefinger and thumb gives a release stick sign as total removal of lubricating starch is approached. This is a palpable and audible sign denoting effective removal of starch.

An experiment was designed to count the number of starch granules remaining on surgical gloves (Regent Dispo surgeons' gloves) after removal by the above method and by other methods and when no attempt was made to remove the powder at all. Ten pairs of gloves were subjected to each

Efficacy of seven methods of removing starch from surgeons' gloves

\begin{tabular}{|c|c|c|c|}
\hline Method & $\begin{array}{l}\text { Median } \\
\text { No of } \\
\text { starch } \\
\text { granules } \\
\text { remaining } \mathrm{mm}^{2}\end{array}$ & $\begin{array}{l}\text { No of } \\
\text { gloves } \\
\text { with } 100 \% \\
\text { starch } \\
\text { removed }\end{array}$ & $\begin{array}{l}\text { Significance of } \\
\text { remaining starch } \\
\text { compared with } \\
\text { method } \\
(1)^{*}\end{array}$ \\
\hline \multirow{6}{*}{$\begin{array}{l}\text { (1) One minute cleanse with Betadine, } \\
30 \text {-second rinse } \\
\text { (2) } 30 \text {-second cleanse with Betadine, } \\
30 \text {-second rinse } \\
\text { (3) } 30 \text {-second scrub with Betadine } \\
\text { using brush, } 30 \text {-second rinse } \\
\text { (4) } 30 \text {-second scrub in bowl } \\
\text { containing } 1 \text { litre } 5^{\circ} \text {, Betadine } \\
\text { (5) } 30 \text {-second scrub using brush } \\
\text { in } 1 \text { litre water } \\
\text { (6) } 30 \text {-second rinse in } 1 \text { litre water in } \\
\text { bowl } \\
\text { (7) No attempt at removing powder }\end{array}$} & 0 & $16 / 20$ & - \\
\hline & $1 \cdot 0$ & 620 & Not significant \\
\hline & $1 \cdot 3$ & $8 / 20$ & $\mathrm{p}=0.015$ \\
\hline & $17 \cdot 5$ & 0 & $p<0.001$ \\
\hline & $24 \cdot 85$ & 0 & $p<0.001$ \\
\hline & $\begin{array}{r}264 \\
2720\end{array}$ & $\begin{array}{l}0 \\
0\end{array}$ & $\begin{array}{l}p<0.001 \\
p<0.001\end{array}$ \\
\hline
\end{tabular}

*Significance of difference from method (1) by Mann-Whitney U test. method (see table), yielding 20 gloves for analysis. A $2 \mathrm{~cm}$ area was cut from the palmar aspect of the gloves. This was dried and stained with Lugol's iodine. ${ }^{4}$ The sample was mounted on a slide and examined by light microscopy. Starch granules were stained blue-black. Three $1 \mathrm{~mm}$ areas were counted to give a median number of granules per $\mathrm{mm}^{2}$. The table gives the results.

\section{Comment}

Surgeons might think that using a scrubbing brush (methods 3, 4, 5 ) is potentially dangerous in promoting formation of small perforations in the glove. Rinsing the gloves in water leaves about $10 \%$ of the original starch content on the surface of the glove (method 6).

If surgeons wish to remove starch then a thorough cleanse with povidone-iodine surgical scrub for one minute followed by a rinse in running sterile water removes $99 \cdot 8-100 \%$ of the original count and provides the surgeon with a reassuring aurotactile stick sign. The sticking of the gloves disappears once the tissue fluids from patients' wounds coat the gloves. It is important that all members of the surgical and nursing team participating in the operation follow this method to prevent contamination of the operative site with maize starch.

I thank Napp Laboratories Limited for supplying the Betadine, LRC Products Limited for donating the Regent Dispo surgeons' gloves, Miss Lynne Jarrett for typing the manuscript, and Mr Byron Walmsley for performing the statistical analysis.

1 Anonymous. Glove powder: a surgical hazard. $\operatorname{Br}$ Med $\mathcal{f} 1973 ; \mathrm{i}: 502-3$.

2 Anonymous. Hazards of surgical glove powders. Br Med $\mathcal{f} 1980 ; 281$ :892-3.

3 Jagelman DG, Ellis H. Starch and intraperitoneal adhesion formation. Br 7 Surg 1973;60:111-4.

4 Jourdan MH, Lyttle JA, McColl I. Removal of starch from two types of surgical glove. Br f Surg 1978;65:360-1.

${ }^{5}$ Fraser I. Hazards of surgical glove powders. Br Med $\mathcal{F}$ 1980;281 :1072.

(Accepted 2 April 1982)

University Surgical Unit, Southampton General Hospital, Southampton SO1 6HU

IAN FRASER, MS, FRCS, lecturer in surgery

\section{Prednisone in amiodarone-induced thyrotoxicosis}

Thyrotoxicosis has been observed during ${ }^{12}$ and after ${ }^{23}$ treatment with the iodine-containing antiarrhythmic drug, amiodarone, in patients with and without pre-existing thyroid disease. Among those without thyroid disease several patients have had a diffuse, soft, and painless goitre which disappeared after withdrawal of amiodarone. ${ }^{1}$ These patients had severe clinical thyrotoxicosis similar to that after accidental or medical exposure to a large amount of iodine. ${ }^{14}$ Once symptoms of hyperthyroidism have developed treatment is a serious problem, as the fully iodinated thyroglobulin stores preclude a prompt response to drugs of the thionamid type and the WolffChaikoff effect (the inhibition of the synthesis of thyroid hormone after administration of large doses of iodide) prevents the use of additional free iodine. Chopra ${ }^{5}$ observed a decrease in serum concentrations of $\mathrm{T} 3$ and $\mathrm{T} 4$ during treatment with dexamethasone. We therefore assessed the effect of prednisone on two patients with thyrotoxicosis, one case occurring during and the other after treatment with amiodarone.

\section{Case reports}

Case 1-After two years of successful treatment with amiodarone for recurrent supraventricular tachycardia, thyrotoxicosis with weight loss, insomnia, and permanent tachycardia developed in a 60-year-old man. Amiodarone was stopped, and on admission to hospital he was found to have a small, soft, and non-tender goitre. He was given a two-week course of prednisone (figure, top) after which T4 and T3 concentrations were normal. They rose again after prednisone withdrawal, $\mathrm{T} 4$ to a thyrotoxic level and T3 to a high normal level. When treatment with prednisone was restarted, the hormone concentrations fell again. The dose was tapered during the next two months. T4 and T3 concentrations remained normal after prednisone was discontinued and the goitre disappeared iour months after the end of amiodarone treatment. 
Case 2-A 40-year-old man was given amiodarone because of recurrent supraventricular tachycardia. After two years the drug was stopped because the arrhythmia was well controlled. One month later he showed clinical signs of thyrotoxicosis and had a small non-tender goitre. In-vitro T3 uptake was $50 \%$. Despite three weeks' treatment with carbimazole $60 \mathrm{mg} /$ day the patient lost $10 \mathrm{~kg}$ in weight. On admission to hospital he had tachycardia, was sweating profusely, and had myopathy. Antibodies against thyroglobulin were $1 / 16$ (positive) but were negative against microsomal antigen. Serum $\mathrm{T} 4$ and $\mathrm{T} 3$ concentrations were very high (figure, bottom). Urinary iodine
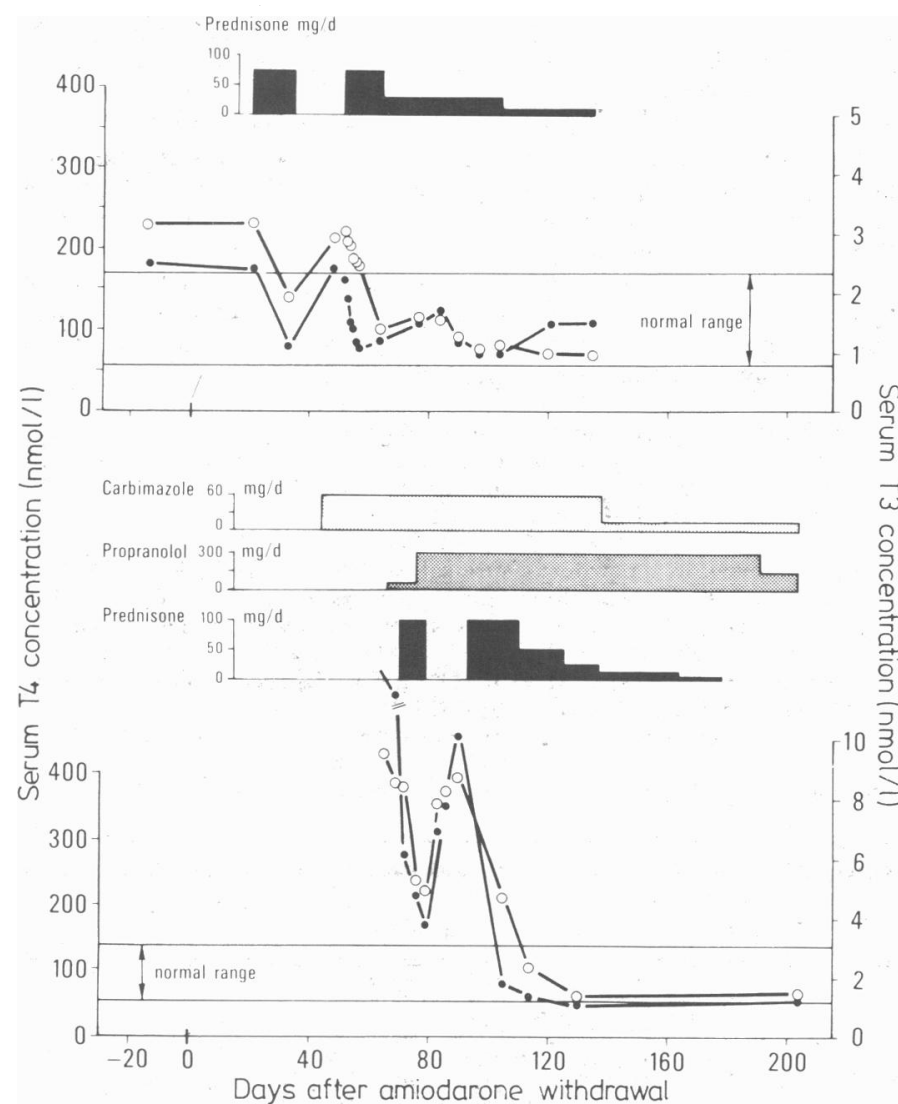

Serum T3 and T4 concentrations: (top) during treatment with prednisone alone (case 1) and (bottom) after addition of prednisone to treatment with carbimazole and propranolol (case 2). As the values in the cases were measured with different radioimmunoassays the absolute figures are not comparable.

excretion was $66 \mu \mathrm{mol} /$ day (normal range $0 \cdot 8-1.6 \mu \mathrm{mol} /$ day). The patient was given propranolol and prednisone; carbimazole was continued. During prednisone treatment $\mathrm{T} 4$ and $\mathrm{T} 3$ concentrations fell rapidly. They promptly rose again after the drug was stopped. A second course of prednisone was therefore given and the dose tapered when the hormone concentrations decreased. The goitre had disappeared five months after amiodarone treatment had been stopped; thyroglobulin antibodies were absent and the patient is clinically well.

\section{Comment}

Thyrotoxicosis occurred during amiodarone treatment in case 1 and after treatment in case 2. Both patients had a transient, non-tender goitre. During prednisone treatme at T4 and T3 concentrations fell and the condition of both patients improved. This effect was confirmed when prednisone treatment was interrupted; hormone concentrations rose again and clinical deterioration was evident.

Apparently, prednisone shortens the duration of the rise in concentrations of $\mathrm{T} 4$ and $\mathrm{T} 3$; its action on serum hormone concentrations is much more rapid than that of the hormone synthesis blocking drug carbimazole. Prednisone is of particular value if propranolol fails to control the clinical signs of hyperthyroidism (case 2). In case 1 the patient tolerated prednisone without any recognisable side eifects, whereas the patient in case 2 developed transient cushingoid facial signs.

As the use of amiodarone is becoming more and more widespread, a simple and effective treatment for this particular kind of thyrotoxicosis, which is resistant to standard treatment, is needed because of the long-lasting iodine overload of the thyroid during and after amiodarone treatment.

We thank Professor H Bürgi, Bürgerspital, Solothurn, and Dr S Burkhardt, Muri, Switzerland, for the clinical and laboratory data.

Correspondence and requests for reprints should be addressed to: Dr M Stäubli, Department of Medicine, Inselspital, 3010 Bern, Switzerland.

1 Savoie JC, Massin JP, Thomopoulos P, Leger F. Iodine-induced thyrotoxicosis in apparently normal thyroid glands. F Clin Endocrinol 1975 41 : $685-91$.

2 Jonckheer $\mathrm{MH}$, Broeckaert I, Blockx P, Bernard R. Amiodarone et fonction thyroidienne. Arch Mal Coeur 1976;69:1315-9.

${ }^{3}$ Burger A, Dinicheret D, Nicod P, Jenny $M$, Lemarchand-Béraud $T$, Valloton MB. Effect of amiodarone on serum triiodothyronin, reverse triiodothyronine, thyroxin, and thyrotropin. 7 Clin Invest 1976;58:255-9

${ }^{4}$ Blum M, Weinberg U, Shenkmann L, Hollander CS. Hyperthyroidism after iodinated contrast media. $N$ Engl f Med 1974;291:24-5.

${ }^{5}$ Chopra IJ, Williams DE, Origiazzi J, Solomon DH. Opposite effects of dexamethasone on serum concentrations of 3,3',5'-triiodothyronine (reverse T3) and 3,3',5-triiodothyronine (T3). 7 Clin Endocrinol Metab $1975 ; 41: 911-20$

(Accepted 30 March 1982)

University Department of Medicine, Inselspital, Bern, Switzerland C WIMPFHEIMER, MD, resident

M ST ÄUBLI, MD, senior registrar

J SCHÄDELIN, MD, senior registrar

H STUDER, MD, professor and head of department

\section{Overt diabetes mellitus without glycosuria in a patient with cutaneous ureteroileostomy}

Though a positive result to a urine test for glucose requires further investigation, a negative result by no means excludes diabetes. The classic cause of a false-negative result is a high renal threshold for glucose, which is present in advanced renal failure. Another cause that is not often remembered is a ureteroenterostomy. We report a case of overt diabetes mellitus without glycosuria in a patient with an ileal conduit and normal renal function.

\section{Case report}

A 59-year-old Caucasian man was admitted for investigation with a sixmonth history of unusual lethargy. Two years previously he had had a radical cystectomy with ileal loop urinary diversion for bladder cancer and had since remained well. $\mathrm{He}$ was not taking any drugs; his weigit, appetite, urine output, and stoma function were normal. Examination of the heart, lungs, abdomen, stoma, eyes, and nervous system showed no abnormalities. Urinalysis one hour after eating showed a $\mathrm{pH}$ of 8 , proteinuria + , and no glucose or ketones. Laboratory study showed a haemoglobin concentration of 14 $\mathrm{g} / \mathrm{dl}$, a leucocyte count of $5.8 \times 10^{9} / 1$ with normal differentials, a normal platelet count, and an erythrocyte sedimentation rate of $30 \mathrm{~mm}$ in the first hour. Plasma sodium concentration was $135 \mathrm{mmol}(\mathrm{mEq}) / 1$, potassium $3 \cdot 00$ $\mathrm{mmol}(\mathrm{mEq}) / 1$, bicarbonate $14 \mathrm{mmol}(\mathrm{mEq}) / 1$, urea $6.2 \mathrm{mmol} / 1(37 \mathrm{mg} / 100 \mathrm{ml})$, creatinine $0.11 \mathrm{mmol} / 1(12.4 \mathrm{mg} / 100 \mathrm{ml})$, and chloride $115 \mathrm{mmol}(\mathrm{mEq}) / 1$. Blood sugar concentration measured at random was $20.5 \mathrm{mmol} / \mathrm{l}(369 \mathrm{mg} / 100$ $\mathrm{ml}$ ), and two fasting concentrations were 17.8 and $16.5 \mathrm{mmol} / 1$ (320 and 297 $\mathrm{mg} / 100 \mathrm{ml}$ ) respectively. Appearances on chest $x$-ray and electrocardiogram were normal. His 24-hour urine volume was $1400 \mathrm{ml}$, creatinine clearance $84 \mathrm{ml} / \mathrm{min}$, and total proteinuria $0.2 \mathrm{~g}$. Results of an excretory urogram were normal. Midstream urine culture grew no pathogens, and daily urine testing for glucose gave negative results throughout his stay in hospital.

He was treated with insulin and potassium supplements and subsequently discharged taking glibenclamide and sodium bicarbonate. Four weeks after discharge his fasting plasma glucose, bicarbonate, and potassium concentrations had returned to normal, and he remained well.

\section{Comment}

Though diabetics with an ileal conduit may have glycosuria, total reabsorption of glucose from the loop may sometimes occur. ${ }^{1}$ This case is representative of the occasional patient whose urine may be negative for sugar and thereby mislead the unwary clinician. The appearance of glucose in urine normally depends on three factors: the plasma

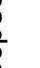

